\title{
Reese-Ellsworth Classification Group II
}

National Cancer Institute

\section{Source}

National Cancer Institute. Reese-Ellsworth Classification Group II. NCI Thesaurus. Code C123364.

Favorable for maintenance of sight. 